\title{
Penggunaan Multimedia Interaktif (MMI) Sebagai Media Pembelajaran Dalam Meningkatkan Prestasi Belajar Fisika
}

\author{
Ana S. Rahmawati ${ }^{*}$, Rahmawati P. Dewi ${ }^{2}$ \\ ${ }^{1}$ Program Studi Pendidikan Fisika, Universitas Flores \\ ${ }^{2}$ SMK Negeri 2 Ende \\ *Email: anarahmawati734@gmail.com
}

DOI: http://dx.doi.org/10.29303/jpft.v5i1.958

\begin{abstract}
The purpose of this study was to determine the use of interactive multimedia as a learning medium in improving physics learning achievement. This type of research is an experimental design one group pre-test post-test with a quantitative approach. The population in the study were all students of class X semester 2 of SMK Negeri 2 Ende which consisted of 13 classes in 5 skill programs totaling 421 people and the sample of the research was 26 students of TKJ class XC as many as 26 people. The sampling technique was purposive sampling. Data collection techniques in this study are achievement test techniques. Data were analyzed by t test. The results showed that the use of interactive multimedia (MMI) as a learning medium can improve physics learning achievement. This is evidenced by the value of $t$ count $>t$ table or 3.491>1.708 with the degree of freedom to list the distribution $t$ is $d k=N-1=$ $26-1=25$, and the significance level is 0.05 .
\end{abstract}

Keywords: Interactive Multimedia, Learning Media, Learning Achievement

\section{PENDAHULUAN}

Pendidikan merupakan suatu kegiatan yang universal. Pendidikan meliputi banyak ilmu pengetahuan termasuk diantaranya adalah sains. Fisika merupakan salah satu bagian dari sains (Husein S., dkk., 2015) Besarnya peran fisika dalam dunia pendidikan terutama dalam pengembangan teknologi telah menempatkan fisika sebagai pelajaran strategis yang memegang peranan penting serta perlu diajarkan di sekolah. Melalui pembelajaran fisika, diharapkan siswa dapat memperoleh pengetahuan, keterampilan, dan sejumlah kemampuan lainnya (Rahmatiah et al. 2016). Namun saat ini pembelajaran fisika di sekolah selalu mengalami titik jenuh bagi para siswa, disamping banyaknya rumus yang harus dihafal siswa juga selalu mendapatkan suasana yang membosankan. Oleh karena itu pembelajaran fisika harus dibuat lebih menarik dan mudah dipahami, karena fisika lebih membutuhkan pemahaman dari pada penghafalan berbagai rumus yang begitu banyak. Untuk mengantisipasi hal tersebut salah satunya perlu didukung media pembelajaran yang sesuai. Proses pembelajaran di sekolah sangat membutuhkan strategi dalam penyampaian dan sistem evaluasi yang tepat. Strategi itu dapat berupa pembelajaran yang mempesona, menyenangkan, menarik, mengasyikan, tidak membosankan, variatif kreatif dan indah (Rohmatika, 2006). Bertolak dari kenyataan itu, hendaknya proses pembelajaran yang dilakukan oleh guru lebih ditekankan pada penggunaan media pembelajaran yang sesuai dengan kemajuan teknologi, sehingga dapat menarik perhatian siswa serta membantu siswa untuk lebih mudah memahami konsep alam yang dipelajari.

Menurut Widada (2010), salah satu media pembelajaran yang menarik perhatian bagi siswa di era teknologi informasi ini adalah berbasis multimedia. Perkembangan teknologi komputer menghadirkan inovasi dalam proses pembelajaran sains, khususnya fisika (Gunawan et al. 2015). Media pembelajaran berbasis multimedia ini menyajikan tampilan multidimensional yang memungkinkan siswa dapat mengerjakan, 
mendengar dan melihat dalam waktu yang bersamaan sehingga proses pembelajaran lebih bersifat interaktif.

\section{Media pembelajaran}

Menurut Sadiman (2003), kata media berasal dari bahasa latin dan merupakan bentuk jamak dari kata medium yang secara harfiah berarti perantara atau pengantar. Media adalah segala sesuatu yang dapat digunakan untuk menyalurkan pesan dari pengirim ke penerima sehingga dapat merangsang pikiran, perasaan, perhatian, dan minat serta perhatian siswa sedemikian rupa sehingga proses belajar terjadi. Pembelajaran adalah usaha mengelola lingkungan dengan sengaja agar seseorang membentuk diri secara positif dalam kondisi tertentu (Miarso, 2004). Menurut Widada (2010), media pembelajaran merupakan alat bantu dalam proses pembelajaran. Media pembelajaran yang baik harus memenuhi beberapa kriteria, antara lain: kesesuaian dengan materi pembelajaran, kemudahan dalam penggunaan dan menarik bagi siswa sehingga tercapai tujuan pembelajaran secara optimal. Handhika (2012) mengemukakan bahwa, media pembelajaran memiliki manfaat khusus yang dapat dijadikan pertimbangan sebagai subjek penelitian, diantaranya: (1) Penyampaian materi dapat diseragamkan, (2) Proses pembelajaran menjadi lebih menarik, (3) Proses belajar siswa lebih interaktif, (4) Jumlah waktu pembelajaran dapat dikurangi, (5) Kualitas belajar siswa dapat ditingkatkan, (6) Proses pembelajaran dapat terjadi dimana saja dan kapan saja, (7) Peran guru dapat berubah ke arah yang lebih positif dan produktif.

Berdasarakan uraian dari hasil penelitian dan pendapat para ahli di atas maka dapat disimpulkan bahwa media pembelajaran merupakan alat bantu dalam proses pembelajaran yang harus memiliki sifat menarik, interaktif, kesesuaian dengan materi pembelajaran fisika yang akan diajarkan, mudah digunakan oleh siswa, mengefektifkan dan menghemat waktu pembelajaran sehingga menciptakan suasana menyenangkan dalam proses pembelajaran fisika.

\section{Multimedia interaktif}

Multimedia adalah pemanfaatan komputer untuk membuat dan menggabungan teks, grafik, audio dan gambar bergerak (video dan animasi) yang memungkinkan pengguna berinteraksi, berkreasi dan berkomunikasi serta menghidupkan teks dengan menyertakan bunyi, gambar, musik, animasi, dan video (Suyanto, 2005). Sistem pendukung keputusan yang berbasis komputer dianggap bersifat interaktif (Magdalena, 2012). Interaktif memberikan kesan apa yang dapat dilakukan siswa terhadap media (Handhika, 2012). Nandi (2006) menyatakan bahwa, siswa juga dapat berinteraksi dengan latihan soal yang disediakan. Selain itu, DePorter (2005) mengatakan bahwa, 90\% masukan indra untuk otak berasal dari sumber visual, dan otak mempunyai tanggapan cepat dan alami terhadap simbol, ikon dan gambar yang sederhana dan kuat. Hal tersebut dapat memberikan pengaruh positif sehingga siswa akan lebih mudah memahami konsep fisika jika konsep tersebut divisualisasikan dari pada dijelaskan dengan kata-kata atau cerita saja. Menurut Fauziah dan Andryana (2012), multimedia interaktif adalah bila dalam suatu aplikasi terdapat seluruh elemen multimedia yang ada dan pengguna diberi kebebasan atau kemampuan untuk mengontrol dan menghidupkan elemenelemen tersebut.

Berdasarkan uraian di atas maka dapat disimpulkan bahwa multimedia interaktif merupakan media pembelajaran yang di dalamnya terdapat seluruh elemen multimedia yang disajikan secara interaktif sehingga siswa diberi kebebasan atau 
kemampuan untuk mengontrol dan berinteraksi dengan media tersebut.

Multimedia interaktif yang digunakan dalam penelitian pembelajaran fisika ini adalah berupa software Adobe Flash. Adobe Flash adalah suatu program animasi grafis yang banyak digunakan para desainer grafis untuk menghasilkan karyakarya profesional. Kelebihan flash terletak pada kemampuannya menghasilkan animasi gerak dan suara. Adobe flash merupakan salah satu program komputer yang dapat digunakan untuk membuat visualisasi dari suatu proses yang tidak terlihat maupun yang abstrak sama sekali tidak berwujud, yang memiliki kemampuan untuk menampilkan multimedia, gabungan antar grafis, animasi, suara serta interaktifitas (Wijaya, 2003).

Berdasarkan uraian di atas maka dapat dikatakan bahwa, adobe flash merupakan salah satu program yang dapat dimanfaatkan secara efektif sebagai pendukung media pembelajaran multimedia interaktif.

\section{Komputer}

Komputer adalah alat elektronik otomatis yang dapat menghitung atau mengolah data secara cermat menurut yang diinstruksikan dan memberi hasil pengolahan serta dapat menjalankan sistem multimedia (film, musik, televisi, faxmile dan sebagainya) (KBBI offline, 2011). Berdasarkan pengertian tersebut maka dapat dikatakan bahwa, komputer dapat digunakan sebagai alat pendukung proses pembelajaran yang menggunakan multimedia interaktif sebagai media pembelajaran karena dapat menjalankan segala proses interaktif yang terjadi selama penggunaan media pembelajaran multimedia interaktif tersebut.

\section{Prestasi Belajar fisika}

Prestasi belajar didefinisikan sebagai tingkat penguasaan materi yang dicapai oleh siswa setelah mengikuti proses belajar mengajar sesuai dengan tujuan pendidikan yang diharapkan, yang hasilnya ditunjukan oleh skor atau angka (Poerwadarminto, 2004). Menurut Winkel (2004), prestasi belajar merupakan bukti keberhasilan yang telah dicapai oleh seseorang. Berdasarkan pendapat-pendapat tersebut dapat disimpulkan bahwa prestasi belajar merupakan hasil yang telah dicapai seseorang dalam bentuk pengetahuan dan kecakapan setelah melakukan pembelajaran yang ditentukan melalui penilaian dan pengukuran.

Pada penelitian ini, prestasi belajar yang dimaksud adalah prestasi belajar fisika dalam mempelajari materi Perpindahan Kalor dengan menggunakan media pembelajaran lab virtual yang ditunjukkan dengan angka dari hasil tes akhir. Dalam penelitian ini aspek yang digunakan untuk mengukur prestasi belajar adalah (Sudjana, 2011) bidang kognitif (Penguasaan Intelektual). Bidang ini berhubungan dengan kemampuan berfikir siswa dari tingkat rendah berupa pengetahuan hafalan sampai tingkat tinggi berupa evaluasi.

a. Pengetahuan Hafalan (Knowledge)

Cakupan dalam pengetahuan hafalan termasuk pula pengetahuan yang sifatnya faktual, disamping pengetahuan mengenai hal-hal yang perlu diingat kembali seperti batasan, peristilahan, pasal, hukum, bab, ayat, rumus, dan lainnya.

b. Pemahaman (comprehention)

Pemahaman lebih tinggi satu tingkat dari pengetahuan hafalan. Pemahaman memerlukan kemampuan menangkap makna atau arti dari suatu konsep.

c. Penerapan (aplication)

Aplikasi adalah kesanggupan menerapkan dan mengabstraksikan suatu konsep, ide, rumus, hukum dalam situasi yang baru. 
d. Analisis

Analisis adalah kesanggupan memecah, mengurai suatu kesatuan yang utuh menjadi unsur-unsur yang mempunyai arti. Analisis merupakan tipe hasil belajar yang kompleks yang memanfaatkan tipe hasil belajar sebelumnya.

e. Sintesis

Sintesis merupakan kesanggupan menyatukan unsur-unsur atau bagian menjadi suatu kesatuan yang utuh. Sintesis memerlukan kemampuan hafalan, pemahaman, aplikasi dan analisis.

f. Evaluasi

Evaluasi adalah kesanggupan memberikan keputusan tentang nilai sesuatu berdasarkan kemampuan yang dimilikinya dan kriteria yang dipakainya. Tipe hasil belajar ini dikategorikan paling tinggi dan terkandung semua tipe hasil belajar sebelumnya. Dalam evaluasi tekanan pada pertimbangan sesuatu nilai, mengenai baik tidaknya, dengan menggunakan kriteria tertentu.

Dari uraian di atas dapat disimpulkan bahwa bidang kognitif merupakan suatu ranah yang berhubungan dengan kemampuan berfikir yang mengandung enam tingkatan yaitu pengetahuan, pemahaman, aplikasi, analisis, sintesis, dan evaluasi. Proses penilaian bidang kognitif dengan menggunakan posttest dan lembar evaluasi setelah kegiatan belajar mengajar selesai.

Faktor-faktor yang mempengaruhi prestasi belajar adalah sebagai berikut (Mulyasa, 2007): (1) Faktor eksternal: faktor eksternal yang dapat mempengaruhi prestasi belajar peserta didik adalah faktor sosial dan faktor non sosial; (2) Faktor internal: sekalipun banyak pengaruh atau rangsangan dari faktor eksternal yang mendorong individu untuk belajar, keberhasilan belajar itu akan ditentukan oleh faktor diri (internal) beserta usaha yang dilakukannya. Faktorfaktor internal mencakup: (a) Faktor-faktor fisiologis, yang menyangkut keadaan jasmani atau fisik individu, yang dibedakan menjadi dua yaitu keadaan jasmani pada umumnya dan keadaan fungsi-fungsi jasmani tertentu terutama panca indera; (b) Faktor-faktor psikologis, yang berasal dari dalam diri seperti intelegensi, minat, sikap dan motivasi.

\section{Tes prestasi}

Tes adalah suatu alat pengukur berupa serangkaian pertanyaan yang harus dijawab dalam situasi tertentu yang dimaksudkan untuk mengukur kemampuan dan hasil belajar (Arikunto, 2009). Tes prestasi pada umumnya digunakan untuk mengukur tingkat penguasaan dan kemampuan siswa secara individual dalam cakupan ilmu pengetahuan yang telah ditentukan oleh guru setelah siswa melaksanakan proses pembelajaran selama waktu tertentu (Sukardi, 2011). Berdasarkan pendapat-pendapat di atas maka dapat disimpulkan, bahwa tes prestasi adalah alat pengukur berupa serangkaian pertanyaan yang digunakan untuk mengukur kemampuan siswa setelah melaksanakan proses pembelajaran selama waktu tertentu.

Berdasarkan pertimbanganpertimbangan tersebut maka dilakukanlah penelitian tentang penggunaan multimedia interaktif (MMI) sebagai media pembelajaran dalam meningkatkan prestasi belajar fisika. Tujuan dari penelitian ini adalah untuk mengetahui peningkatan prestasi belajar fisika jika menggunakan multimedia interaktif (MMI) sebagai media pembelajaran.

\section{METODE PENELITIAN}

Jenis penelitian ini merupakan penelitian eksperimen. Adapun prosedur penelitian yang dilakukan adalah sebagai berikut: 
1. Tahap persiapan

a. Menyiapkan buku-buku yang berkaitan dengan materi kemudian materi tersebut dimasukan ke komputer lalu dimodifikasi menggunakan adobe flash.

b. Menyiapkan silabus dan rencana pelaksanaan pembelajaran.

c. Menyiapkan garis besar.

d. Menyusun soal yang berkaitan dengan materi perpindahan kalor.

e. Melakukan uji coba pada kelas yang lebih tinggi untuk memilih soal-soal yang akan digunakan pada tes awal dan tes akhir.

2. Tahap pelaksanaan

Pada tahap ini, peneliti melaksanakan kegiatan pembelajaran di kelas sesuai dengan materi yang diteliti dan media pembelajaran yang digunakan. Adapun hal-hal yang perlu dilakukan dalam tahap ini adalah: (a) Mamberikan tes awal; (b) Memberikan perlakuan berupa penerapan media pembelajaran multimedia interaktif; dan (c) Memberikan tes akhir.

3. Tahap Akhir

Pada tahap ini, peneliti melakukan analisis data.

Desain penelitian dapat dilihat pada Tabel 1 .

Tabel 1. Desain Penelitian

\begin{tabular}{ccccc}
\hline Kelas & $\begin{array}{c}\text { Pre } \\
\text { test }\end{array}$ & Perlakuan & $\begin{array}{c}\text { Post } \\
\text { test }\end{array}$ & Hasil \\
\hline $\mathrm{MI}$ & $\mathrm{Y}_{1}$ & $\mathrm{X}$ & $\mathrm{Y}_{2}$ & $\mathrm{~A}$ \\
\hline
\end{tabular}

Keterangan:

MI = Multimedia Interaktif

$\mathrm{Y}_{1} \quad=$ Skor tes awal.

$\mathrm{X}=$ Perlakuan berupa penerapan media pembelajaran multimedia interaktif

$\mathrm{Y}_{2}=$ Skor tes akhir.

Populasi dalam penelitian ini adalah seluruh siswa kelas $\mathrm{X}$ semester 2 SMK Negeri 2 Ende yang terdiri dari 13 kelas dalam 5 program keahlian yang berjumlah 421 orang. Sedangkan Ssmpel yang diambil adalah kelas XC TKJ Semester 2 yang berjumlah 26 orang. Teknik pengambilan sampel yang digunakan dalam penelitian ini adalah purposive sampling. Teknik yang digunakan dalam penelitian ini adalah teknik pengukuran kependidikan yaitu tes prestasi. Dalam menetapkan jumlah dan bentuk tes prestasi dalam rangka mengumpulkan data, peneliti menggunakan instrumen penelitian berupa seperangkat soal yang berjumlah 50 butir soal dan yang digunakan adalah soal objektif pilihan ganda dengan lima alternatif pilihan jawaban a, b, c, d dan e setiap soal hanya memiliki satu jawaban yang benar. Adapun pemberian skor pada setiap butir soal adalah apabila jawaban benar diberi skor 1 dan jika jawaban salah diberi skor 0 . Peneliti melakukan uji coba soal tersebut pada siswa kelas XI dan kemudian menghitung validitas, reliabilitas, taraf kesukaran soal dan daya pembeda soal sebelum memberikan tes awal dan tes akhir. Software yang peneliti gunakan untuk melakukan pengujian instrumen adalah AnatesV4. Selanjutnya, analisis data yang digunakan pada penelitian ini adalah dengan uji-t satu sampel dan digunakan untuk mengetahui perbedaan rata - rata untuk satu sample (Trianto, 2009).

\section{HASIL DAN PEMBAHASAN}

Sebelum tes digunakan dalam penelitian ini, awalnya dilakukan uji coba pada kelas XI Semester 2 SMK Negeri 1 Ende. Maksud dilakukan uji coba adalah untuk mengetahui validitas, reliabilitas, tingkat kesukaran butir soal (TK) dan daya pembeda soal (DP). Jumlah butir tes yang digunakan dalam uji coba ini adalah sebanyak 50 butir soal. Setelah uji coba dilakukan, selanjutnya penulis mengoreksi guna memberi nilai hasil uji coba sekaligus menentukan validitas, reliabilitas, tingkat kesukaran butir soal (TK), dan daya pembeda soal (DP). Dari hasil pengujian tersebut diperoleh 26 item soal yang memenuhi keempat kriteria tersebut. Setelah 
dilakukan tes awal dan tes akhir, data selisih nilai tes awal dan tes akhir tersebut digunakan untuk menguji normalitas dan data nilai tes akhir prestasi belajar digunakan untuk menguji hipotesis.

Dengan jumlah siswa 26 orang dari data yang diperoleh ternyata nilai tertinggi yang dicapai pada tes awal adalah 52 dan nilai terendah 12 dengan rata-rata $(\mathrm{X} 1)=$ 32,76 , varians $(\mathrm{S} 12)=267,5$ dan simpangan baku $(\mathrm{S} 1)=16,35$. Selanjutnya pada tes akhir diperoleh nilai tertinggi adalah 92 dan nilai terendah 72 dengan rata-rata $(\mathrm{X} 2)=$ 79,54 , varians $(\mathrm{S} 22)=43,94$ dan simpangan baku $(\mathrm{S} 2)=6,63$ dan selisih nilai diperoleh nilai tertinggi adalah 68 dan nilai terendah 28 dengan rata-rata $(X)=46,77$, varians (S2) $=2964,18$ dan simpangan baku $(\mathrm{S})=54,44$.

Tabel 2. Data hasil tes prestasi belajar

\begin{tabular}{lccc}
\hline & $\begin{array}{c}\text { Tes } \\
\text { Awal } \\
(\text { Pretest })\end{array}$ & $\begin{array}{c}\text { Tes } \\
\text { Akhir } \\
(\text { Posttest })\end{array}$ & $\begin{array}{c}\text { Selisih } \\
\text { Nilai }\end{array}$ \\
\hline $\begin{array}{l}\text { Nilai } \\
\text { Tertinggi } \\
(\mathbf{X})\end{array}$ & 52 & 92 & 68 \\
\hline $\begin{array}{l}\text { Nilai } \\
\text { Terendah } \\
(\mathbf{X})\end{array}$ & 12 & 72 & 28 \\
\hline Mean & 32.76 & 79.54 & 46.77 \\
\hline $\begin{array}{l}\text { Varians } \\
\left(\mathbf{S}^{2}\right)\end{array}$ & 267.5 & 43.94 & 2964.18 \\
\hline $\begin{array}{l}\text { Standar } \\
\text { Deviasi } \\
(\text { S) }\end{array}$ & 16.35 & 6.63 & 54.44 \\
\hline $\begin{array}{l}\text { Jumlah } \\
\text { Siswa (N) }\end{array}$ & 26 & & \\
\hline
\end{tabular}

Kemampuan kelas sampel diukur dengan cara diberi tes prestasi belajar. Tes prestasi awal diberikan sebelum perlakuan dan tes prestasi akhir diberikan setelah perlakuan. Data nilai prestasi belajar diuji lagi untuk mengetahui apakah data tersebut memenuhi uji prasyarat analisis dan uji hipotesis.

1. Hasil uji prasyarat analisis

Pengujian prasyarat analisis dalam penelitian menggunakan uji normalitas. Dari perhitungan diperoleh nilai $X^{2}$ hitung 6,792 dengan derajat kebebasan $(d k)=6-3=3$, pada taraf signifikan 5\% $(\alpha=0,05)$ diperoleh nilai $X^{2}$ tabel 7,815 . Karena nilai $X^{2}$ hitung < $X_{\text {tabel }}^{2}=6,792<7,815$ maka data ini terdistribusi normal.

2. Hasil uji hipotesis

Hasil perhitungan dengan thitung $=$ 3,491 sedangkan $t_{\text {tabel }}=1,708$. Dimana $t_{\text {hitung }}$ $>t_{\text {tabel }}=3,491>1,708$ maka $\mathrm{H}_{\mathrm{a}}$ diterima sedangkan $\mathrm{H}_{0}$ ditolak sehingga dapat disimpulkan bahwa pengunaan multimedia interaktif sebagai media pembelajaran dapat meningkatkan prestasi belajar fisika siswa.

Dalam penelitian ini media pembelajaran yang digunakan adalah multimedia interaktif. Penerapan media pembelajaran ini membuat siswa lebih aktif dalam kegiatan pembelajaran, dimana siswa diberi kesempatan untuk melihat sehingga mereka dapat mengalami sendiri, mengikuti suatu proses, menganalisis, membuktikan dan menarik kesimpulan sendiri mengenai obyek, keadaan, atau proses dengan mencoba memahami dan menarik kesimpulan yang dialaminya. Sehingga siswa lebih percaya dengan apa yang ia lihat dan konsep tersebut dapat bertahan lama dalam ingatan siswa.

Prosedur penelitian ini diawali dengan mempersiapkan perangkat pembelajaran dan instrumen penelitian. Sebelum instrumen penelitian digunakan, awalnya instrumen tersebut diuji coba pada kelas atas untuk mengetahui apakah instrumen tersebut memenuhi kriteria soal yang baik, yaitu valid, reliabel, taraf kesukaran soal sedang dan daya pembeda soal baik. Setelah instrumen tersebut memenuhi keempat kriteria tersebut maka instrumen tersebut siap digunakan untuk mengetes kemampuan awal siswa sebelum diberi perlakuan dengan menerapkan media pembelajaran interaktif. Setelah mengetahui kemampuan awal siswa, peneliti mulai memberi perlakuan pada kelas sampel dengan menerapkan media pembelajaran 
interaktif. Dalam proses pembelajaran, siswa terlihat sangat aktif dalam mengikuti pembelajaran serta respon siswa sangat baik. Materi yang diajarkan adalah perpindahan kalor secara konveksi, konduksi dan radiasi. Sebelum pembelajaran dimulai, peneliti memberikan tes awal kepada siswa untuk mengkur kemampuan dasar siswa.

Setelah selesai pembelajaran, siswa diberi tes akhir. Perbedaan hasil tes prestasi pada awal dan akhir ini yang akan dianalisis untuk mengetahui keberhasilan penggunaan media.

\section{Implementasi media pembelajaran}

Program yang digunakan untuk membangun media pembelajaran multimedia interaktif adalah adobe flash (Gambar).

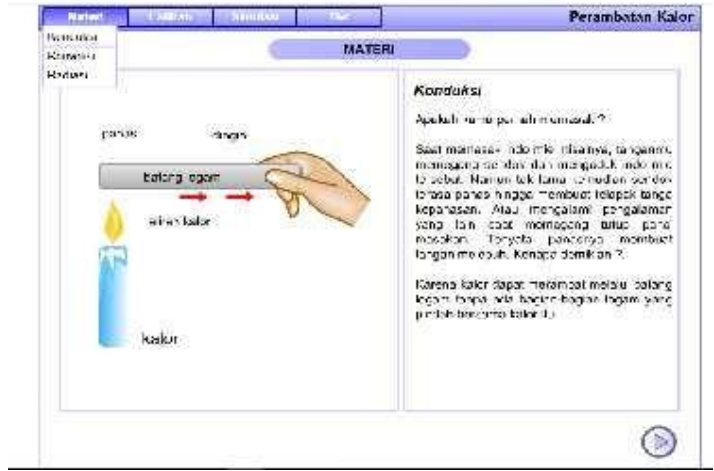

Gambar 1. Media pembelajaran multimedia interaktif adobe flash

Media pembelajaran multimedia interaktif memiliki tiga sub menu utama, yaitu sub menu konduksi, sub menu konveksi dan sub menu radiasi. Sub menu konduksi berisi pembahasan mengenai peristiwa konduksi, pengertian konduksi, simulasi peristiwa konduksi, dan laju hantaran kalor konduksi secara matematis. Sub menu konveksi menjelaskan tentang pengertian perpindahan kalor secara konveksi, simulasi tentang peristiwa perpindahan kalor secara konveksi, laju hantaran kalor konveksi ditulis secara matematis dan macam macam perpindahan kalor secara konveksi. Sedangkan sub menu radiasi membahas tentang pengertian perpindahan kalor secara radiasi, simulasi peristiwa radiasi, laju hantaran kalor radiasi ditulis secara matematis. Ketiga sub menu tersebut dilengkapi dengan soal latihan dan pembahasannya serta simulasinya. Tampilan untuk masing-masing sub menu beserta penjelasannya dapat dilihat pada Gambar 2, Gambar 3, dan Gambar 4 berikut ini.

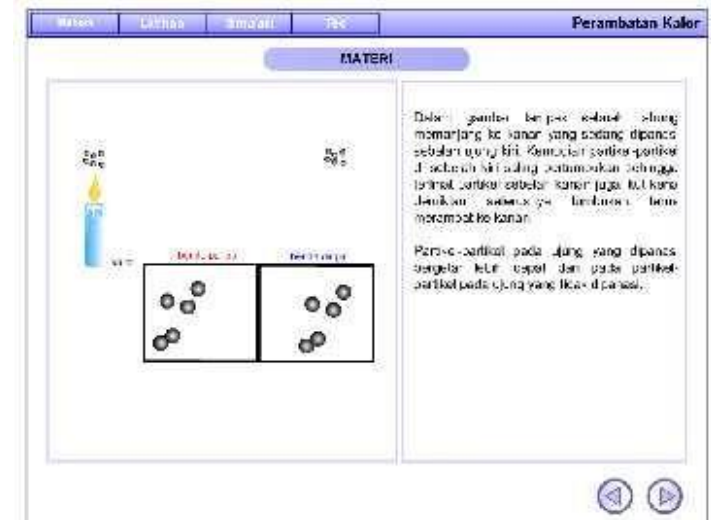

Gambar 2. Submenu perpindahan kalor secara konduksi

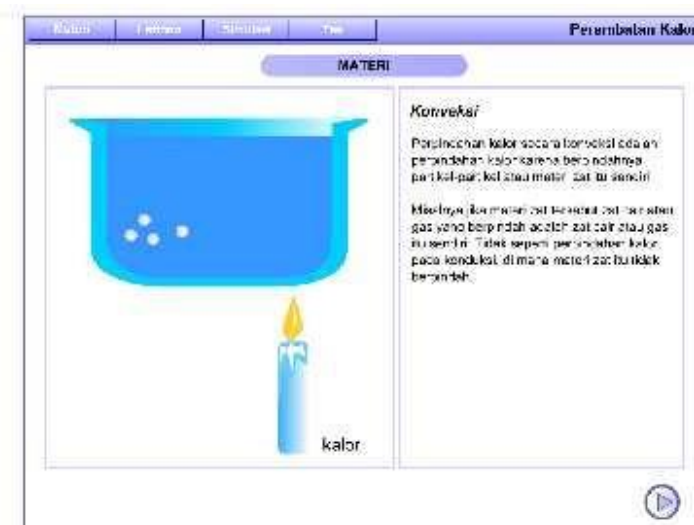

Gambar 3. Submenu perpindahan kalor secara konveksi

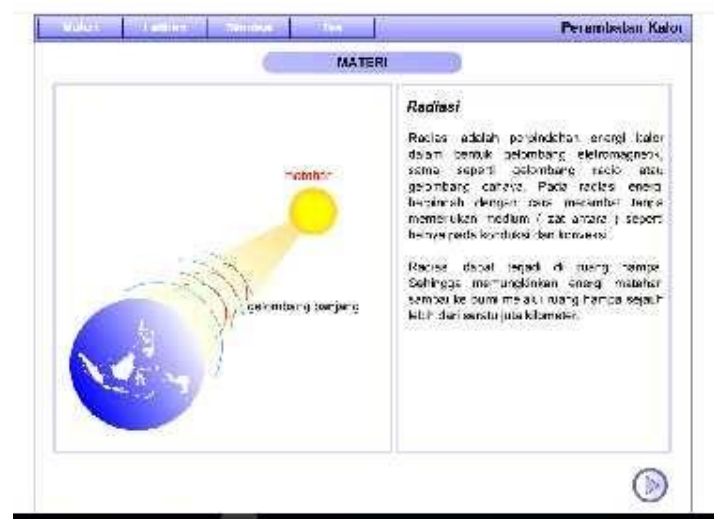

Gambar 4. Submenu perpindahan kalor secara radiasi 


\section{Hasil implementasi media pembelajaran}

Dari hasil yang diperoleh setelah perlakuan yaitu penerapan multimedia interaktif sebagai media pembelajaran telah menunjukkan adanya perbedaan hasil nilai tes awal dan tes akhir pada prestasi belajar fisika siswa. Hal ini dibuktikan oleh hasil penelitian yang dilakukan pada taraf signifikan $(\alpha)=0,05$ dengan peluang $(1-\alpha)$, ternyata prestasi belajar fisika siswa meningkat dengan nilai $t_{\text {hitung }}>t_{\text {tabel }}=3,484$ $>1,708$ setelah diberi perlakuan yaitu pengunaan multimedia interaktif sebagai media pembelajaran pada materi ajar perpindahan kalor untuk siswa kelas $\mathrm{X}$ SMK Negeri 2 Ende.

\section{PENUTUP}

Penerapan multimedia interaktif sebagai media pembelajaran dapat meningkatkan prestasi belajar fisika siswa minimal mencapai nilai 75 pada materi ajar dinamika partikel untuk siswa kelas X SMK Negeri 1 Ende. Hal ini terbukti dengan hasil analisis data yaitu $t_{\text {hitung }}>t_{\text {tabel }}=3,491>$ 1,708 dengan derajat kebebasan $(d k)=26-$ $1=25$, peluang $(1-\alpha)$ dan taraf signifikan $(\alpha)=0,05.7$, maka ada beberapa hal yang dapat disarankan oleh penulis sebagai berikut:

1. Guru diharapkan mampu menentukan dan menggunakan media pembelajaran yang dapat menarik minat belajar siswa serta mampu menciptakan suasanan pembelajaran yang efektif dan menyenangkan.

2. Guru diharapkan memperluas pemahaman dan wawasan di bidang ilmu pengetahuan dan teknologi khususnya teknologi multimedia sehingga media pembelajaran yang dipilih dapat disesuaikan dengan perkembangan teknologi yang ada.

3. Guru diharapkan memilih dan menggunakan media pembelajaran yang tepat dalam melaksanakan proses pembelajaran sesuai dengan materi yang diajarkan.

4. Guru diharapkan membantu dan memperhatikan siswa yang mengalami kesulitan dalam menyelesaikan soalsoal fisika.

\section{REFERENSI}

Arikunto, S. 2009. Dasar-dasar Evaluasi Pendidikan. Jakarta: Bumi Aksara.

DePorter, B. 2005, Quantum Teaching: Mempraktikkan Quantum Learning di Ruang Kelas. Bandung: Kaifa.

Fauziah \& Andriyana, S. 2012. WEB Portal Berbasis Teknologi Multimedia Menggunakan Bahasa Pemrograman Vidiscript. SemnasIF 2012. ISSN: 1979-2328. pp. D65D69.

Gunawan, Harjono, A., Sutrio. 2015. Multimedia Interaktif dalam pembelajaran konsep listrik bagi calon guru. Jurnal Pendidikan Fisika dan Teknologi. I (1). 9-14.

Handhika, J. 2012. Efektifitas Media Pembelajaran IM3 ditinjau dari Motivasi Belajar. Jurnal Pendidikian IPA Indonesia (JPII) 1(2), 109-114.

Husein, S., Lovy, H., Gunawan. 2015. Pengaruh penggunaan multimedia interaktif terhadap penguasaan konsep dan keterampilan berpikir kritis siswa pada materi suhu dan kalor. Jurnal Pendidikan Fisika dan Teknologi. I (3). 221-225.

\section{KBBI offline. 2011. (http://pusatbahasa.kemdiknas.go.id /kbbi/).}

Magdalena, H. 2012. Model Pengambilan Keputusan untuk Memilih Software Berbasis Open Source untuk Aplikasi Digital Library Berbasis WEB, Seminar Nasional Teknologi Informasi dan Komunikasi 2012 (SENTIKA 2012), ISSN: 2089-9815. Yogyakarta. 
Miarso, Y. 2004. Menyemai Benih Teknologi Pendidikan. Jakarta: Prenada Media.

Nandi. 2006. Penggunaan multimedia interaktif dalam pembelajaran geografi di persekolahan, Jurnal "GEA" Jurusan Pendidikan Geografi. 6(1), 1-9.

Rahmatiah, R., Supriyono K.H., Sentot K. 2016. Pengaruh scaffolding konseptual dalam pembelajaran group Investigation terhadap prestasi belajar fisika siswa SMA dengan pengetahuan awal berbeda. Jurnal Pendidikan Fisika dan Teknologi. II(2). 45-54.

Rohmatika, R. 2006. Efektivitas Penerapan MMI dengan Metode Diskusi Terhadap Fisika Siswa SMP, Jurnal Pendidikan, .

Sudjana, N. 2011. Metode Statistik Edisi Kelima. Bandung: Transito.

Sukardi. 2011. Metodologi Penelitian Pendidikan. Jakarta: Bumi Aksara.

Suyanto, M. 2005. Multimedia Alat untuk Meningkatkan Keunggulan Bersaing. Yogyakarta: ANDI Offset.

Trianto. 2009. Mengembangkan Model Pembelajaran Tematik. Jakarta: Prestasi Pustaka.

Widada, H.R. (2010). Mudah membuat Media Pembelajaran Tematik. Jakarta: Prestasi Pustaka.

Wijaya, D. 2003. Macromedia Flash Mx dengan Action Script-Tip dan Trik. Jakarta: PT Elex Media Komputindo.

Winkel, W. S. 2004. Psikologi Pengajaran. Yogyakarta: Media Abadi. 